\title{
High-Speed Cutting of Bearing Rings from Material 100Cr6
}

Josef Sedlak, Pavel Tropp, Josef Chladil, Karel Osicka, Petra Sliwkova

Department of Machining Technology, Institute of Manufacturing Technology, Faculty of Mechanical Engineering, Brno University of Technology, Technická 2896/2, Brno 616 69, Czech Republic. E-mail: sedlak@fme.vutbr.cz, TroppPavel@seznam.cz, chladil@fme.vutbr.cz, osicka@fme.vutbr.cz, sliwkova@fme.vutbr.cz

An article deals with a concept of increasing efficiency of a current production process of bearing ring machining. A goal is to substitute a generally expensive technology of cutting when at least the same integrity of a surface is kept. A theoretical part is focused on a characteristic and analysis of a given component including an applied material 100Cr6 from which bearing rings are made. A practical part analyses and suggests an innovation of increasing efficiency of the machining process. Series of samples would be tested experimentally at university conditions (Workroom C2 of Dept. of Machining Technology, Faculty of Mechanical Engineering, Brno University of Technology) using CNC Lathe Machine SP 280 SY.

The article describes individual production workplaces along with used tool equipment that includes for the process of increasing efficiency the innovation in the form of the change of the production process, changes of most cutting tools and cutting conditions needed for the turning of heat-treated bearing rings. The article also deals with a surface integrity after turning of bearing rings. The integrity is analysed using a touch measuring tools (a manual roughness tester TS100, a tool with an inductive sensor Form Talysurf Intra) and using a touchless measuring tool Alicona Infinite Forces G4, including the measurement of a residual tension in a surface layer (Barkhausen noise) by the tool Rollscan 300 .

The article finishes with a wear test of replaceable cutting blades at applied cutting conditions with a follow-up discussion, which describes problematic steps that were done in particular phases of experimental testing, and with necessary concept of further testing of bearing rings.

Keywords: High-Speed Cutting, Hard Materials, 100Cr6, Bearing Rings, Turning, Surface Integrity

\section{Acknowledgement}

The research was supported and co-financed from a project of Ministry of Industry and Trade of the Czech Republic from a grant FR-TI4/247 Research and Development of Construction and Technology of Energetically Efficient Rolled Bearings with Brass Cage.

\section{References}

[1] SCHULZ, H., SCHÜTZER, K. The History of High-Speed Machining. [Online]. Germany: Sao Paolo: Ed. Erica, 2004 [seen $18^{\text {th }}$ March 2015]. Available at: http://www.unimep.br/phpg/editora/revistaspdf/rct13art01.pdf.

[2] SKOPECEK, T., VODICKA, J., PAHL, J. P., HERKNER V. (2005). Basics of High-speed Machining - HSC. $1^{\text {st }}$ edition. Plzen: University of West Bohemia. ISBN 80-704-3344-2.

[3] SKOPECEK, T., SVOBODA, J., REHOR, J., HOFMANN, P. (2003). Creation of Chip during High-speed Machining. MM Industrial Spectre - Technical Monthly for Czech and Slovak Republic, April, num. 4., p. 18, ISSN 1212-2572.

[4] BARCUCH, J. (2013). Optimization of Tool Cutting Geometry for High-speed Machining of Thin-sided Components. Brno. Master Thesis. Brno University of Technology, Faculty of Mechanical Engineering, Dept. of Machining Technology. 79 p. Advisor prof. Ing. Miroslav Piska, CSc.

[5] Bohdan Bolzano, Ltd. Czech Republic. Material List of Steel 14 109. [Online]. (C 2015. August 2003 [seen $6^{\text {th }}$ June 2015]. Available at: http://www.bolzano.cz/.

[6] Low-alloyed Construction Steel Class 14, Their Composition and Heat Treatment. TumliKOVO: Technology of Mechanical Machining of Metals. [Online]. 2015 [seen 24 ${ }^{\text {th }}$ April 2015]. Available at: http://www.tumlikovo.cz/nizkolegovane-konstrukcni-oceli-tridy-14-jejich-slozeni-a-tepelne-zpracovani/.

[7] FR-TI4/247, Research and Development of Construction and Technology of Energetically Efficient Roller Bearings with Brass Cage, (2012 to 2015, MPO Czech Republic). Leader: doc. Ing. Josef Chladil, CSc.

[8] SEDLAK, J., FISEROVA, Z., CHLADIL, J., ZEMCIK, O., DVORACEK, J. (2013). Influence of Lubricants on Durability of Roller Bearings. Journal PROCEEDINGS IN MANUFACTURING SYSTEMS, Vol. 8, No. 4, p. 213-220. ISSN 2067-9238. 
[9] ZEMCIK, O., CHLADIL, J., OTOUPALIK, J., SEDLAK, J. (2013). Changes in Surface Layer of Rolled Bearing Steel. Journal PROCEEDINGS IN MANUFACTURING SYSTEMS, Vol. 8, No. 2, p. 99-104. ISSN $2067-$ 9238.

[10]OSICKA, K., CHLADIL, J., KALIVODA, M., OTOUPALIK, J. (2014). Contribution to Turning Hardened Steel. Journal of International Scientific Publications: Materials, Methods and Technologies, Vol. 8, No. VI, p. 705-712. ISSN 1314-7269.

[11]OSICKA, K., FISEROVA, Z., OTOUPALIK, J. (2015). Influence of Cutting Tool Overhangs at Machining of Hardened Steels. Manufacturing TECHNOLOGY, Vol. 15, No. 2, p. 188-191. ISSN 1213-2489.

[12]SECO Tools. SECO Tools. [Online]. 2015 [seen $11^{\text {th }}$ May 2015]. Available at: https://www.secotools.com/.

[13]NESLUSAN, M. (2013). Monitoring of Surface Integrity after Cutting of Alloyed Bearing Steels with Use of Barkhausen Noise. Žilina: University of Zilina, Mechanical Faculty. 23 p.

[14]DURSTOVA, Z., MICIETA, B., CILLIKOVA, M., NESLUSAN, M., MRAZIK, J. (2014). Non-destructive Magnetic Evaluation of Ground Surfaces Made of Bearing Steel of Variable Hardness. Manufacturing TECHNOLOGY, Vol. 14, No. 3, p. 297-303. ISSN 1213-2489.

[15]HRABOVSKY, T., NESLUSAN, M., MICIETA, B., ClLIKOVA, M., MICIETOVA, A. (2014). Barkhausen Noise Emission of Surfaces Produced by Hard Milling Process. Manufacturing TECHNOLOGY, Vol. 14, No. 1, p. 17-23. ISSN 1213-2489.

[16]TROPP, P. (2015). High-Speed Cutting of Bearing Rings from Material 100Cr6. Brno. Master's Thesis. Brno University of Technology, Faculty of Mechanical Engineering, Department of Machining Technology. 92 pp., 6 pp. Appendices. Supervisor doc. Ing. Josef Sedlak, Ph.D. 